\title{
The Derbyshire General Infirmary and the Derby Philosophers: The Application of Industrial Architecture and Technology to Medical Institutions in Early-Nineteenth-Century England
}

\author{
PAUL ELLIOTT*
}

\begin{abstract}
I
Though there have been various studies of hospital architecture, few have examined in detail the application of industrial technology to medical institutions in the Enlightenment and early-nineteenth-century periods. ${ }^{1}$ This paper tries to rectify this by offering a case study of one hospital, the Derbyshire General Infirmary (1810), where, principally under the inspiration of the cotton manufacturer, William Strutt FRS (1756-1830), a deliberate attempt was made to incorporate into a medical institution the latest "fireproof" building techniques with technology developed for
\end{abstract}

* Paul Elliott, School of Geography, University of
Nottingham, University Park, Nottingham, NG7
2RD.

I am grateful to Desmond King-Hele, Jonathan Barry, Anne Borsay, William F Bynum and John Pickstone for their helpful criticisms, and to John Pickstone for sending me copies of a couple of his papers.

${ }^{1}$ B Abel-Smith, The hospitals 1880-1948: a study in social administration in England and Wales, London, Heinemann, 1964; A Berry, 'Patronage, funding and the hospital patient $c$. 1750-1815: three English regional case studies', DPhil thesis, University of Oxford, 1995; S Cherry, 'The role of English provincial voluntary general hospitals in the eighteenth and nineteenth centuries', 2 vols, PhD thesis, University of East Anglia, 1976; L Granshaw, 'The hospital', in W F Bynum and R Porter (eds), Companion encyclopedia of the history of medicine, London, Routledge, 1993, vol. 1, pp. 1180-203; L Granshaw and R Porter (eds), The hospital in history, London, Routledge, 1989; J V Pickstone, Medicine and industrial society: a history of hospital development in Manchester and its region, 1752-1946, Manchester University Press, 1985; J V Pickstone and S V F Butler, 'The politics of medicine in Manchester, 1788-1792: hospital reform and public health services in the early industrial city', Med. Hist., 1984, 28: 227-49; F N L Poynter (ed.), The evolution of hospitals in Britain, London, Pitman Medical, 1968; L Prior, 'The architecture of the hospital: a study of spatial organisation and medical knowledge', $\mathrm{Br}$. J. Sociol., 1988, 39: pp. 86-113; H Richardson (ed.), English hospitals, 1660-1948: a survey of their architecture and design, Swindon, Royal Commission on the Historical Monuments of England, 1998; E M Sigsworth, 'Gateways to death? Medicine, hospitals and mortality, 1700-1850', in P Mathias (ed.), Science and society, 1600-1900, Cambridge University Press, 1972, pp. 97-110; J Taylor, Hospital and asylum architecture in England, 1840-1914: building for health care, London, Mansell, 1991; J D Thompson and G Goldin, The hospital: a social and architectural history, New Haven, Yale University Press, 1975; C Webster, 'The crisis of the hospitals during the industrial revolution', in E G Forbes (ed.), Human implications of scientific advance: proceedings of the 15th International Congress of the History of Science, Edinburgh, 1977, Edinburgh University Press, 1978, pp. 214-23; John Woodward, To do the sick no harm: a study of the British voluntary hospital system to 1875, London, Routledge \& Kegan Paul, 1974. 


\section{Paul Elliott}

textile mills. ${ }^{2}$ In fact, the Derbyshire Infirmary provides one of the most interesting examples in Industrial Revolution Britain of the direct application of novel industrial technology and organization to medical institutions for clinical and moral purposes defined and enforced by the donors, and encapsulates many of the features of the Enlightenment institutional and theoretical medical revolution. Informed by Foucauldian theories of discipline and power, the Weberian and Frankfurt School concept of instrumental rationality, and recent work on hospital design by historians of medicine, this paper examines the motivation behind-and the impact of - the design and technology of the Derbyshire Infirmary. It seeks to determine how successful the Infirmary was as, in Foucault's phrase, a "curing machine" serving as an instrument of power, through an assessment of the clinical impact of the technology, using medical statistics and hospital records. The paper also re-affirms the importance of scientific culture in British provincial urban society and the centrality of medical men, whilst demonstrating the role of innovative scientific and technological developments in the increasingly sophisticated control of the urban environment, evident in the discourse of "town improvement" and the medicalization of urban space in the period. Finally, a preliminary assessment is made of the Derbyshire Infirmary's influence on the design of other public and private buildings, particularly medical institutions.

II

Rather than being principally preoccupied with religious or state aggrandisement, Enlightenment architecture became more concerned with the problems of population, health and urban living. The socio-economic changes of the eighteenth century, evident in the population growth and the urban flowering of Georgian Britain, provided new problems of power for the emergent bourgeoisie, requiring more efficacious utilization and control of urban space for politico-economic ends. ${ }^{3}$ These were most acutely felt in the special difficulties of prisons and hospitals, widely recognized to harbour disease, where it became requisite to develop economic systems of control without recourse to brutal restraint and violence. Health and the physical wellbeing of the broad population became "one of the essential objectives of political power", a process which marked a shift from the narrow context of charitable aid

\footnotetext{
${ }^{2} \mathrm{C}$ Sylvester, The philosophy of domestic economy, Nottingham, Longman, Hurst, Rees, Orme \& Brown, 1819; J H H Grant, Derby and Derbyshire Royal Infirmary, Derby, 1924; C L Hacker, 'William Strutt', Derbyshire Archaeological J., 1960, 80: 49-70; V M Leveaux, The history of the Derbyshire General Infirmary, 1810-1894, Cromford, Scarthin Books, 1999. Most of the hospital documents are preserved at Derbyshire County Record Office, Matlock (henceforth DRO).
}

\author{
${ }^{3} \mathrm{P}$ J Corfield, The impact of English towns, \\ 1700-1800, Oxford University Press, 1982; P \\ Clark (ed.), The transformation of English \\ provincial towns, 1600-1800, London, \\ Hutchinson, 1984; P Borsay, The English urban \\ renaissance: culture and society in the provincial \\ town, 1660-1770, Oxford, Clarendon Press, 1989; \\ R Sweet, The English town, 1680-1840: \\ government, society and culture, Harlow, \\ Longman, 1999.
}




\section{The Derbyshire Royal Infirmary}

to the more general form of what Foucault described as "medical police". 4 One result was the development of a more community-oriented medicine evident from the growth of dispensaries which aimed to retain the economic and medical advantages of hospitals whilst supporting family-centred communities. This politicization of space was also evident in the growing role of doctors, who enjoyed an increasingly politically privileged position as the guardians of social hygiene, being invested with powers to manage space. ${ }^{5}$

Another response was a revolution in medical architecture which saw the metamorphoses of hospitals from unspecialized structures - often with the appearance of country gentlemen's seats-into clinically-conditioned functional curing machines. Foucault argued that hospitals were technical and material settings within which discursive formations unfolded and simultaneously constituted the objects to which the discourse was addressed. Space therefore constituted as well as represented social and cultural existence with what Foucault described as the "medical gaze" becoming institutionalized and inscribed in social space. The architecture and design of any given hospital reflected the socio-political realities of its period of construction and the features of prevailing medical knowledge. The problem faced by Enlightenment philosophers, philanthropists, architects and governing committees was to retain control over the labour force and optimize their utility whilst avoiding overcrowding, undue contact and physical proximity. The aim was "to set the able-bodied poor to work and transform them into a useful labour force" with the greatest economy. ${ }^{6}$ Hence the great attention paid to hospital design in the Enlightenment period and afterwards, when the problems of the location, spatial adaptation and organization were articulated and widely discussed by medical men and philanthropists such as the Quaker John Howard (1726-1790) and the Gloucestershire magistrate Sir George Onesiphorus Paul (1746-1820). There was a revival of ancient Hippocratic concerns with an emphasis on healthy, well watered and airy locations, where diseases could also be successfully isolated from the rest of the labouring population.

The creation of effective curing machines also required a re-organization of the internal space in hospitals. This included providing technological answers to the problems of heating and the circulation of air, whilst requiring the optimization of spacial organization according to therapeutic system, evident, for instance, in the separation of groups of patients by disease characteristics into small wards, in contrast to the larger wards which had been common. ${ }^{7}$ Philanthropists such as

\footnotetext{
${ }^{4} \mathrm{M}$ Foucault, The birth of the clinic: an archaeology of medical perception, London, Routledge, 1989; idem, 'The eye of power: a conversation with Jean-Pierre Barou and Michelle Perrot'; and idem, 'The politics of health in the eighteenth century', in C Gordon (ed.), Michel Foucault: power/knowledge, selected interviews and other writings, 1972-1977, New York, Harvester Wheatsheaf, 1980, pp. 146-65, 166-82; 'Space, power and knowledge', an interview with Paul Rabinow in, $\mathrm{P}$ Rabinow, The Foucault reader, New York, Pantheon, 1984; Prior, op. cit., note 1 above, pp. 86-113.
}

\footnotetext{
${ }^{5}$ For dispensaries in Georgian England, see Z Cope, 'The history of the dispensary movement', in Poynter (ed.), op. cit., note 1 above, pp. 73-6; I S L Loudon, 'The origins and growth of the dispensary movement in England', Bull. Hist. Med., 1981, 55: 322-42; B Croxson, 'The public and private faces of eighteenth-century London dispensary charity', Med. Hist., 1997, 41: 127-49.

${ }^{6}$ Foucault, 'The politics of health', op. cit., note 4 above, p. 169.

${ }^{7}$ Ibid., pp. 179-82.
} 
Howard and Paul drew attention to the poor conditions that existed in some institutions, which, it was suggested, harboured diseases often considered to be spread by aerial contagion and which were, likewise, frequently associated with the spread of vice. With the creation of a systematic science of quantifiable and definable "airs", it became evident that natural philosophy and medical theory could contribute to the prevention of disease, which gave renewed impetus to Hippocratic concerns about the external factors of disease causation. According to miasmic theory, expounded in Britain by physicians such as William Cullen (1710-1790), a poisonous "miasma" emanated from sources of corruption such as rotting meat or diseased bodies, and this either originated or exacerbated diseases prevalent on ships or in public institutions such as hospitals and prisons. ${ }^{8}$ Prisons and hospitals shared some of the same problems in that both required separation of their subjects, either as punishment or for clinical reasons, but in so doing, both were thought to make the control of disease problematic because of the difficulties of heating and ventilating separate rooms or cells. Attempting to reduce the incidence of disease in ships and public buildings, for instance, the clergyman Stephen Hales knocked ventilator holes into prison walls and invented a giant fan system to supply fresh air and remove the stale. He was convinced that placing ventilators at Newgate Prison in 1752 significantly decreased the mortality and sickness rates. ${ }^{9}$ Likewise, after touring hundreds of prisons and hospitals throughout Europe, Howard made recommendations about the location, design, structure and appearance of these institutions, suggesting that they should be in open country where possible. Furthermore, the Scottish physicians James Lind (1716-1794) and Sir John Pringle (1707-1782) used their experiences working for the British navy and army respectively to investigate the relationship between putrefaction, contagion and fever, both suggesting that the effluvia of typhus sufferers could be diluted or weakened through the practice of cleanliness and particularly the provision of efficient ventilation systems. John Haygarth (1740-1827) of Chester took this further by advocating the creation of separate fever wards which would allow separate treatment and help to prevent epidemics within crowded towns. ${ }^{10}$ Experiments with hospital design also took place in Enlightenment France culminating in Jacques Tenon's influential Mémoires sur les hôpitaux de Paris (1788). Hugues de Maret, of the Lyons Hospital, experimented with meat hung in wards and demonstrated that foul air fell to the

\footnotetext{
${ }^{8} \mathrm{C}$ Hannaway, 'Environment and miasmata', and $M$ Pelling, 'Contagion/germ theory/ specificity', in Bynum and Porter (eds), op. cit., note 1 above, vol. 1, pp. 292-308, 309-334; C Hamlin, 'Predisposing causes and public health in early nineteenth century medical thought', Soc. Hist. Med., 1992, 5: 43-70; J Riley, The eighteenth-century campaign to avoid disease, Basingstoke, Macmillan, 1987.

9 'Ventilator', in A Rees, The cyclopaedia; or, universal dictionary of arts, sciences and literature, London, Longman, Hurst, Rees, Orme \& Browne, 1819-20, vol. 36; R Evans, The fabrication of virtue: English prison architecture,
}

1750-1840, Cambridge University Press, 1982, pp. 94-117.

10 'Fever' and 'Fever Wards', in Rees, op. cit., note 9 above, vol. 14; F M Lobo, 'John Haygarth, smallpox and religious dissent in eighteenth-century England', in A Cunningham and $R$ French (eds), The medical enlightenment of the eighteenth century, Cambridge University Press, 1990, pp. 217-53; see also, W F Bynum, 'Hospital, disease and community: the London Fever Hospital, 1801-1850', in C Rosenberg (ed.), Healing and history, New York, Science History Publications, 1979, pp. 97-115. 


\section{The Derbyshire Royal Infirmary}

floor rather than rising, suggesting that oval wards with rounded edges with extracts at low levels would reduce the problem."

One important source of inspiration for the creation of more efficient curing machines was the adoption of designs, technology and organization modelled on the industrial building techniques, technology and capitalist labour organization being developed in the early British manufactories. This can be viewed as an early example of what Weber and the theorists of the Frankfurt School described as the application of instrumental rationality (or means/end rationality) to all forms of moral, political and economic behaviour. In other words, the shaping of scientific practice according to a model of the natural sciences, the mathematization of experience and knowledge, and the extension of this scientific rationality to many aspects of society. ${ }^{12}$ Under the impact of technological change evident in Britain from the eighteenth century and including both technical apparatus and social process, the individualistic rationality that had been proclaimed and asserted during the humanistic period was transformed into technological rationality. In the capitalist system, individuals were motivated, guided and measured by external standards, being rewarded according to efficiency and technical proficiency, forces which undermined the revolutionary rationalism of the Enlightenment, but also sprang in part from it. Actions were dissolved into a series of semi-spontaneous reactions to prescribed mechanical norms. In industrial society, the machine process imposed patterns of mechanical behaviour, with expediency, convenience and efficiency being rewarded by the competitive market. Teleological and theological dogmas interfered less in the human struggle with matter, whilst experimentalism served to develop a higher efficiency of hierarchical control. Hence, technological rationality became the servant of power in capitalist society and its values spread through the whole of society, making the position of the individual increasingly ambiguous. ${ }^{13}$ One result was the paradoxical irony that the new machinery of power was placed at the mercy of that ultimate form of irrational behaviour-laissez faire capitalism.

In many respects, as Foucault recognized, the problems of power, technology and spacial utilization in Enlightenment public institutions culminated in the Panopticon scheme of the Bentham brothers, which exerted much influence on the design of later prisons, hospitals and other public institutions, though it was never actually constructed. Bentham, of course, argued for a complete re-codification of the law and various rational social and political reforms, modelled on the laws of natural philosophy and guided by the famous Utilitarian principle of bourgeois social felicity.

\footnotetext{
${ }^{11}$ Foucault, The birth of the clinic, op. cit., note 4 above, pp. 39-44.

${ }^{12} \mathrm{H}$ Marcuse, 'Some social implications of modern technology', in A Arato and E Gebhardt (eds), The essential Frankfurt school reader, Oxford, Blackwell, 1978, pp. 138-62; T W Adorno and $\mathrm{M}$ Horkheimer, Dialectic of Enlightenment, London, Verso, 1986; D Held, Introduction to critical theory: Horkheimer to Habermas, London, Hutchinson, 1980, esp. pp. 65-70, 148-74. The inexorable extension of
}

\author{
instrumental reason to social life, from the \\ liberating and emancipating in the Enlightenment \\ to the tyrannical, has also been, of course, one of \\ the concerns of Jürgen Habermas. On some of \\ the problems associated with the use of modern \\ Western conceptions of rationality in history and \\ anthropology, see S Jeyaraja Tambiah, Magic, \\ science and the scope of rationality, Cambridge \\ University Press, 1990. \\ ${ }^{13}$ Marcuse, op. cit., note 12 above.
}




\section{Paul Elliott}

Minimal government was the best government as it allowed the free operation of commerce stimulated by individual achievement, whilst political reform was to be achieved gradually. ${ }^{14}$ The ideological and practical requirement for control through universal observation led them to exploit the possibilities of iron and glass structures in the Panopticon, which attempted to increase the amount of light and transparency for the central controller. An iron structure allowed them to maximize airiness, light, economy and security, whilst the columns could be used for water and the integrated thermo-ventilation system that operated through inter-linked ventilator tubes passing through the cells, allowing observers total control over the conditions of the prisoners. Technology was placed, as Robin Evans has argued, "in the service of a moral order ... an increase, not of efficiency or economy, but of power ... So the earliest attempt to supply a comprehensive technology of services arose from a desire to dominate, not a desire to serve". ${ }^{15}$ This was most evident in Samuel Bentham's design for the Panopticon House of Industry (1797), and the brothers recommended that their designs be extended to manufactories, mad-houses, hospitals and schools. ${ }^{16}$

\section{III}

The design of the Derbyshire Infirmary, which opened for in- and outpatients on 4 June 1810 , is most significant in the history of hospitals because, like the Panopticon, it united some of the greatest preoccupations of European late-Enlightenment architecture, the extension of the principles of scientific rationality to the reform of public institutions, the maintenance of power and control through the re-organization of space, and the development of iron and "fireproof" building structures. The design reflected many of the concerns of Enlightenment philanthropists, wedded to the systems of power and labour control developed by British bourgeois industrialists and businessmen. It was fully described by the chemist and engineer Charles Sylvester (1774-1828), who assisted Strutt with the installation of the technology and later created his own business manufacturing and installing heating systems, whilst playing a leading role in the scientific culture of Derby. ${ }^{17}$

Derby was a growing commercial and industrial town with a population of 13,043 in 1811 , rising to 37,431 by 1841 , many of whom were employed in the cotton and silk manufactories, or as framework knitters. ${ }^{18}$ Commercial and industrial

${ }^{14} \mathrm{~J}$ Bentham, Introduction to the principles of morals and legislation, Oxford, Clarendon Press, 1876; E Halévy, The growth of philosophic radicalism, Boston, Beacon Press, 1960; M Foucault, Discipline and punish: the birth of the prison, London, Penguin Books, 1991, pp. 195-228.

${ }^{15}$ Evans, op. cit., note 9 above, pp. 225-6.

16 'Panopticon; or, the Inspection House' and postscripts, in J Bowring (ed.), The works of Jeremy Bentham, 11 vols, Edinburgh, William Tait, 1838-43, vol. 4, pp. 37-172; Halévy, op. cit., note 14 above, pp. 81-5; Evans, op. cit., note 9 above, ch. 5; Foucault, 'The eye of power', op. cit., note 4 above.
${ }^{17}$ I Inkster, 'Charles Sylvester and the great railway debate', Ann. Sci., 1972, 28: 113-20; idem, 'Studies in the social history of science during the industrial revolution', $\mathrm{PhD}$ thesis, University of Sheffield, 1977, ch. 10; idem, 'The development of a scientific community in Sheffield, 1790-1850: a network of people and interests', Trans. Hunter Archaeological Soc., 1971-77, 10: 99-131.

${ }^{18}$ A W Davison, Derby: its rise and progress, Wakefield, S R Publishers, 1970; M Craven, Derby: an illustrated history, Derby, Breedon Books, 1988; G Turbutt, A history of Derbyshire, 4 vols, Cardiff, Merton Priory Press, 1999. 
families such as the cotton-manufacturing Strutts, Arkwrights, and Evanses and the banking Cromptons enjoyed growing power and influence in the county and challenged traditional landed wealth. ${ }^{19}$ Prior to 1810 , medical relief for the poor and labouring classes in Derby, as in other Georgian towns, took a number of forms. If they could afford it, most sought treatment from apothecaries and surgeons with the help of friendly societies, of which there were nine by 1803 with an average of fifty members each. ${ }^{20}$ For those out of work or unable to work through infirmity or illness, the parish provided some outdoor relief including occasional medical treatment, although there were no infirmaries attached to the workhouses. ${ }^{21}$ A dispensary was founded by the physician Erasmus Darwin FRS (1731-1802) - the inventor, poet and Lunar Society member-after he moved to Derby in 1781, which he hoped would be the "foundation stone of a future infirmary". ${ }^{22}$ The county had also been served from 1786 by two Derbyshire wards in the Nottingham General Infirmary (1782), but Derby remained the last county town in the region without a general hospital.

Georgian Derby had a vibrant literary and philosophical culture which centred on the figures of Darwin and Strutt, both of whom were at the forefront of moves to found a county hospital, with the support of most of the corporation, improvement commissioners, and many local Tories. Darwin was instrumental in the foundation of the Derby Philosophical Society in 1783, which functioned as something of a regional society during his lifetime and was joined by many medical men who used the scientific library. ${ }^{23}$ Most of the group championed town improvements, employing the rhetoric of Enlightenment discourse on social and intellectual progress to justify development and political reform, inspired by Newtonian natural philosophy. Other associates of the Derby savant community instrumental in the establishment of the Infirmary included the theologian, philosopher and social commentator, the Rev. Thomas Gisborne (1758-1846), who offered $£ 5,000$ as the executor of a will. Gisborne had been a founder member of the Derby Society, was a friend of the Manchester

${ }^{19} \mathrm{R}$ S Fitton and A P Wadsworth, The Strutts and Arkwrights, 1758-1830: a study of the early factory system, Manchester University Press, 1958 .

${ }^{20}$ Abstract of the returns ... for the expense and maintenance of the poor in England,

Parliamentary Papers, 1804, xiii, pp. 94-5. This had increased to 15 by 1830 , including a Female Friendly Society founded in 1816 (S Glover, The history, gazeteer and directory of the County of Derby, 2nd ed., Derby, H Mozley, 1829-1833, vol. 2, p. 539).

${ }^{21}$ All Saints Parish, for instance, appointed an apothecary in 1727 chosen by the overseers and churchwardens to take care of the sick poor for $£ 1.10$ s. per year, All Saints Parish, Book of Order, 11 Oct. 1727, quoted in M Hodgkinson, 'Poor relief in All Saints Parish, Derby, 1722-1836, with special reference to the workhouse', BA dissertation, University of Oxford, undated c. 1960 , p. 26.

\footnotetext{
${ }^{22}$ E Krause, Erasmus Darwin, with a preliminary notice by Charles Darwin, London, Murray, 1879, pp. 54-5; Darwin was also surgeon-extraordinary to the Staffordshire General Infirmary from 1783 to 1801 , which gave him some insight into the problems of hospital management: 'Origin and early history of the Staffordshire General Infirmary', in J L Cherry (ed.), Stafford in olden times, 1890, reprinted, Ashbourne, Ashbourne Editions, 1991, pp. 27-8.

${ }^{23}$ E Robinson, 'The Derby Philosophical Society', Ann. Sci., 1953, 9: 359-67; Inkster, 'Studies in the social history of science', op. cit., note 17 above, ch. 7; P Sturges, 'The membership of the Derby Philosophical Society', Midland Hist., 1978, 4: 212-29; D King-Hele, Erasmus Darwin: a life of unequalled achievement, London, Giles de la Mare, 1999; P Elliott, 'The birth of public science in the English provinces: natural philosophy in Derby, c. 1690-1760', Ann. Sci., 2000, 57: 61-100.
} 
physician Thomas Percival, and, with Darwin, an honorary member of the Manchester Literary and Philosophical Society. After Darwin's death, the principal medical inspiration came from the wealthy Europhile physician Richard Forester (1771-1843), who was joined on the design committee appointed in 1804 by wealthy subscribers such as William's brother George Benson Strutt (1761-1841), and Thomas Saxelbye, a Derby chemist, mine owner and lead smelter. In May 1805, Thomas Cox (1770-1842), a Tory lead merchant, Nathaniel Edwards, a Derby attorney, and Dewhurst Bilsborrow (1776-?), a Cambridge-educated physician, were added to the committee. ${ }^{24}$

In many respects the Derbyshire Infirmary design was quite conventional and followed the pattern of hospital building already well established in the scores of voluntary hospitals built in England over the previous eighty years. However, inspired by rapidly evolving industrial architecture - in a county where nearly all of the most important technological developments of the British Industrial Revolution textile industry had hitherto taken place - the Infirmary was one of the first British hospitals to employ an iron and glass structure for the roof (the dome), iron pillars and beams, iron-framed windows and a fire-proof ceiling (over the baths). Although economy and utility were the principal motivating factors in the design, clinical considerations were emphasized by the medical members of the committee. Originally, it was stipulated that the building be "plain and simple and of stone", with a fever ward of twelve beds with a separate entrance, but the final building was much grander and more imposing. The whole was to have eighty beds with two day rooms (one for each sex). ${ }^{25}$ However, although this produced "a great number of plans", many were considered by the committee to be "extremely defective", failing to incorporate satisfactorily the features originally specified. Some showed no special knowledge of the subjects, others were too large and expensive, and generally the designs were considered to pay scant regard to the principle of "greatest economy in the construction", the "convenience" of the medical staff, and the advantages of the patients. These problems reflected the fact that generally accepted standardized and specialized hospital designs were still in dispute during a period of competing medical paradigms and rapid technological and socio-economic change. ${ }^{26}$ The committee therefore "reluctantly" proposed a design of their own which, utilizing "the greatest oeconomy" and "the least possible quantity of walling and roof", was realized by the Derby architect Samuel Brown (b. 1756) who produced the drawings and a model. The design specified small wards with separate and odourless water closets, so that the

\footnotetext{
${ }^{24}$ Meeting of general committee of $£ 50$ subscribers, 9 April 1804; Meeting of general committee, 2 May 1805. Educated at Cambridge where he became a friend of Christopher Wordsworth, Bilsborrow was another protégé of Darwin, who composed poems in his praise and an obituary letter (Monthly Magazine, 1802, 13: 548-9). He apparently began a life of Darwin that was never completed (King-Hele, op. cit., note 23 above, p. 288).

${ }^{25}$ Papers on the establishment of the Derbyshire Infirmary, DRO, D1190/1/1-14;
}

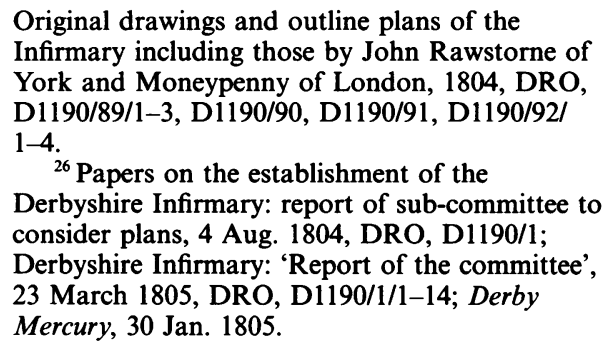
consider plans, 4 Aug. 1804, DRO, D1190/1; Derbyshire Infirmary: 'Report of the committee', 23 March 1805, DRO, D1190/1/1-14; Derby Mercury, 30 Jan. 1805. 


\section{The Derbyshire Royal Infirmary}

medical attendant could "separate acute from chronic diseases and the former from each other as may kill the nature of their complaints". There were to be no "long and sometimes gloomy passages", which had "been so generally adopted" in hospitals, and large convalescent day rooms. A simple means was to be found "of completely and perpetually ventilating every ward with fresh uninhaled air at the same time increasing the temperature by a small expense, to any given degree". This was because "medical men" considered that "in consequence of [a] certain state of the air, which more or less generally pervades hospitals, and which itself has a tendency to produce disease, if the ventilation could be copious while at the same time the warmth could be regulated at pleasure, many lives would be preserved". ${ }^{27}$

Strutt already had much experience of designing bridges and mills, and had played a crucial role in one of the most important revolutions in construction history, the introduction of iron-framed "fire-proof" buildings. ${ }^{28}$ The possibility of using iron for construction appears to have been partly stimulated in his case, as indeed it was generally in Enlightenment Europe, by the demands of bridge building. Improvements in metallurgical processes, some of which were prompted by military requirements, the development of steam power and the adoption of coked coal furnaces, began to reduce the cost of iron and make possible the casting of large-scale iron members for use in construction. In 1791, whilst designing a bridge over the Derwent at Derby and constructing a new cotton manufactory, Strutt asked his associate, the Unitarian Derby hosier, Samuel Fox, to approach Thomas Paine in London for information about the latter's projected iron bridge. ${ }^{29}$ The destruction of a series of manufactories by fire, such as the Evans' mill at Darley Abbey in 1788 and Richard Arkwright's Nottingham mill in 1781 , made the vulnerability of traditional wooden structures apparent, whilst the cost of insurance and replacement emphasized the commercial benefits to be had from devising buildings with greater resistance to fire. In 1792 Strutt obtained detailed information from John Walker, an architect, about Victor Louis' Palais-Royal Theatre in Paris (1785-90), which had succeeded in combining Soufflot's wrought iron roof framing with St Fart's hollow-pot vaulting to eliminate timbering from the structure. Strutt's response, inspired by the French innovations, was a six-storey Derby calico mill (1793-3) that Sylvester described as the "first fireproof mill that was ever constructed", soon followed by a four-storey warehouse at

\footnotetext{
${ }^{27}$ Papers on the Establishment of the Derbyshire Infirmary: report of sub-committee to consider plans, 4 Aug. 1804, DRO, D1190/1/1-14; Derbyshire Infirmary: Report of the Committee, 23 March 1805, DRO, D1190/1/1-14; Derby Mercury, 30 Jan.1805.

28 'Memoir of William Strutt', manuscript, DRO, D2953/mF10/1; Derby Mercury, 12 Jan. 1831; S B Hamilton, 'The use of cast iron in building', Trans. Newcomen Soc., 1940-1, 21: 139-55; T Bannister, 'The first iron-framed buildings', Architectural Rev., 1950, 107: 231-46; H R Johnson and A W Skempton, 'William Strutt's cotton mills, 1793-1812', Trans. Newcomen Soc., 1955-7, 30: 179-205; A W
}

\author{
Skempton and $\mathbf{H} \mathbf{R}$ Johnson, 'The first iron \\ frames', Architectural Rev., 1962, 119: 175-86; \\ M C Egerton, 'The scientific and technological \\ achievements of William Strutt, FRS', MSc \\ thesis, Manchester Institute of Science and \\ Technology, 1967; R Fitzgerald, 'The \\ development of the cast iron frame in textile mills \\ to 1850', Ind. Archaeology Rev., 1988, 10: 127-45; \\ A Menuge, 'The cotton mills of the Derbyshire \\ Derwent and its tributaries', Ind. Archaeology \\ Rev., 1993, 12: 38-61. \\ ${ }_{29} \mathrm{~J}$ G James, 'Thomas Paine's iron bridge \\ work, 1785-1803', Trans. Newcomen Soc., 1987-8, \\ 59: 189-221, p. 203.
}




\section{Paul Elliott}

Milford of similar design. The Derby mill had brick arches with hollow earthenware pots and was paved with brick, though Strutt appears to have remained reluctant to employ iron in the structure at this stage. However, in his plan the pots formed part of the structure rather than being merely to "block out" sections of a floor as at Paris. The girders still used wood (Baltic fir) but were cased in iron. The fourstorey Milford warehouse still stands and is therefore the oldest surviving example of a purpose built, partially iron-framed, fire-resistant building in the world. ${ }^{30}$

Other mill building occurred at Belper and elsewhere, where the design was developed in conjunction with Strutt's friend, the Shrewsbury cotton manufacturer, Charles Bage (1752-1822). Whilst corresponding with Strutt, Bage took the design a stage further by eliminating structural timber altogether and using cast-iron beams supported by cast-iron columns in a five-storey flax mill at Shrewsbury in 1796/97, which was the first true iron-framed building in the world and influenced the construction of other "fire-proof" mills. At around the same time, Strutt was also corresponding with the Bentham brothers on engineering matters, particularly Samuel, whilst they were attempting to realize their iron and glass Panopticon design. He shared the Benthams' interests in refrigeration and glass houses, and later utilized a Panopticon type design in the Belper Round Mill, whilst his son Edward later became an associate of Bentham in London and Philosophical Radical MP for Derby. ${ }^{31}$ Indeed, Benthamism exerted a general influence on the reform leaders at Derby, though in a context in which Bentham and the Derby savant community both inherited a broad Enlightenment philosophy. Sylvester retrospectively stated that the guiding principle that had inspired the Derby hospital was, "to lessen the number of evils to which we are liable, and to increase the sum of our natural and social enjoyments" - which he considered the "end of all philosophical enquiry." 32

Towards the end of the eighteenth century iron also became more common in public buildings such as churches, forming part of the structure rather than being used for decorative effects. Sir John Sloane, for instance, used hollow-pot vaulting in the Bank Stock Office in London (1792-3), and covered the 7 metre (23 feet) diameter oculus over his Consols Office with a twelve-sided iron and glass lantern. The value of incombustible buildings on the plan of the textile mills at Derby and elsewhere to the military was evident, as Sir John Rennie observed in 1807 when advising on the reconstruction of dockyard buildings. ${ }^{33}$ The "fireproof" mill design became most widely known from Strutt's still-surviving Belper north mill (1803-4), which was iron-framed throughout, 127 feet long, 31 feet wide and 63 feet high, and had five storeys and an attic. It became a model for mill construction, an illustration and description by John Farey junior appearing in Rees' Cyclopaedia. ${ }^{34}$

\footnotetext{
${ }^{30}$ Derby Mercury, 20 July 1853; Fitton and Wadsworth, op. cit., note 19 above, pp. 201, 205.

${ }^{31}$ In 1794 Jeremy Bentham wrote to Strutt concerning methods of heating using steam and Samuel Bentham provided Strutt with accounts of steam heating in private houses and discussed the requirements of copper tubing for experiments. He visited Strutt at Derby in 1827 (Strutt correspondence, Derby Local Studies Library [henceforth DLSL], D145/-).
}

\footnotetext{
${ }^{32}$ Sylvester, op. cit., note 2 above; Fitton and Wadsworth, op. cit., note 19 above, p. 181.

${ }^{33}$ Bannister, op. cit., note 28 above, pp. 231-46; Rennie quoted in Bannister, p. 244.

${ }^{34}$ Fitton and Wadsworth, op. cit., note 19, pp. 211-12; J Farey jun., 'Manufacture of cotton', in Rees, op. cit., note 9 above, vol. 22 and vol. 2 of plates. The Belper mill with its teagle or powered lift was also illustrated in A Ure's Philosophy of manufactures, London, C Knight, 1835.
} 


\section{The Derbyshire Royal Infirmary}

Hence, by the time the Derbyshire Infirmary was being designed, Strutt had already introduced novel technology into his manufactories and produced effective "fireproof" buildings. By April 1806, Strutt and the Infirmary design committee had decided to incorporate an iron and glass dome over the centre of the Infirmary, with iron-framed windows and a fire-proof hollow pot-vaulted ceiling over the baths. ${ }^{35}$ Iron was chosen for the dome structure as this allowed six skylights to be incorporated, each consisting of three rows of glass panels, thus maximizing the amount of light shining onto the central hall and staircase, extending the day whilst allowing optimum observation and control by medical staff. The Rev. Davies and the committee considered the dome to be one of the main features to "excite admiration" because "being ... most difficult of execution", it appeared "nevertheless to possess the most perfect strength and solidity". ${ }^{36}$ Apart from Strutt's own recent experience in utilizing iron in construction, it is also significant that Forester, Saxelbye the chemist and Nathaniel Edwards the Derby attorney-two of the other members of the original committee-were partners in one of the largest iron-working businesses in the county, the Riddings Ironworks at Somercotes in Derbyshire, which was awarded the contract for the iron dome. In 1805, just when the decision to construct the dome was being made, they appointed David Mushet (1772-1847), one of the principal metallurgists in Britain, as manager of the works. Although only at Riddings for about three years, Mushet and his brother transformed the complex into the most efficient in the county. Using an improved quality of coke, they roasted the ore in kilns instead of the open air, before heating the coke, ore and flux in a more efficient conical shaped furnace. ${ }^{37} \mathrm{~A}$ decade later Sylvester wrote that "were the Derbyshire Infirmary now to be erected, it would probably be done without any wood being used in its construction; and without even iron pillars and beams", but as it was, the significance of the Derbyshire Infirmary needs to be recognized as probably the earliest general hospital in Britain to utilize in its construction hollow pot and iron-frame technology originally developed for textile manufactories. ${ }^{38}$

The Infirmary was cubical in shape, with the central part being drawn into a conical form, terminating in the dome, which was surmounted by a giant statue of Aesculapius by the local sculptor William Coffee (1773-c.1846) (see Figure 1). A large staircase rose through the centre of the building, surrounded on each of the three floors by small wards and other rooms. The basement contained the baths, cellars and kitchen, and wash-house, whilst the upper storey housed most of the wards (for between four and eight beds each only), operating rooms, convalescent

\footnotetext{
${ }^{35}$ Meeting of the sub-committee, 3 April and 4 Sept. 1806, DRO D1190/1/1-14.

${ }^{36} \mathrm{D}$ P Davies, $A$ new historical and descriptive view of Derbyshire, Belper, S Mason, 1811, p. 240.

${ }^{37}$ Saxelbye and Edwards sold their $2 / 3$ shares to Mushet who subsequently sold them to James Oakes (1750-1828) in 1808, who continued the improvements, whilst Forester remained in partnership with Oakes. R Johnson, $A$ history of Alfreton, Ripley, G C Brittain, 1969, pp. 127-30; 'David Mushet', Dictionary of national biography, London, Smith, Elder, 1894, vol. 39, pp. 429-30;
}

J Farey, General view of the agriculture ... of Derbyshire, 3 vols, London, B McMillan, 1811-17, vol. 1, pp. 399-400; R M Healey (ed.), The diary of George Mushet, 1805-1813, Derbyshire Archaeological Society, 1982.

${ }^{38}$ Dr Edward Fox, however, incorporated fireproof construction including iron window frames, staircases, joists and doors at Brislington House private asylum near Bristol c. 1804 (Richardson (ed.), op. cit., note 1 above, pp. 157-8). 


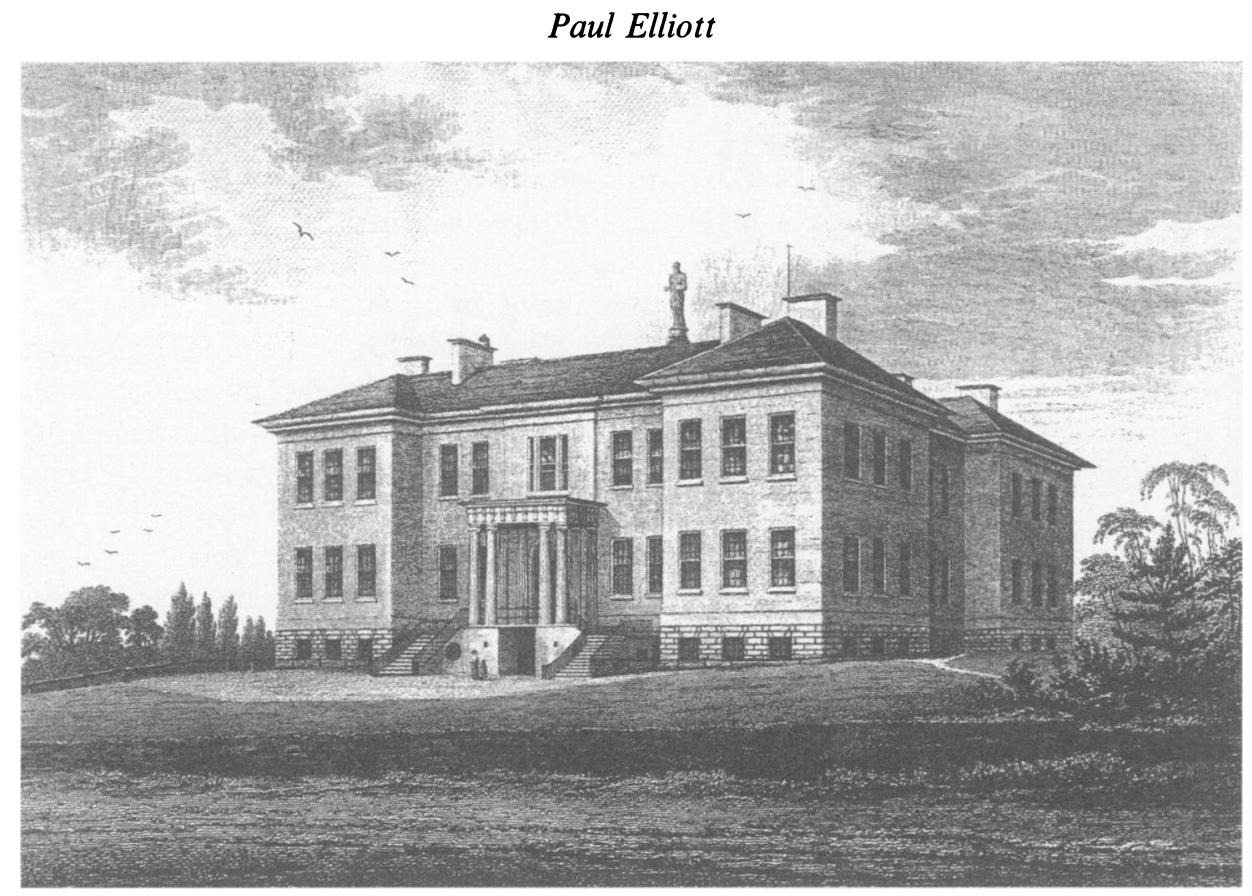

Figure 1: Engraving of the exterior of the Derbyshire Infirmary by $\mathrm{J}$ Pye after a drawing by Edward Goodwin, from Charles Sylvester The philosophy of domestic economy, Nottingham, H Barnett, 1819.

rooms and the fever wing. Significantly, the middle storey, which was fronted by the main public entrance, besides housing a couple of wards and the outpatients' room and chapel, contained the board room, servants' quarters and the rooms of the medical staff (see Figure 2). This ensured that any visitors who came through the imposing millstone grit Doric column portico, passed the board room and matron's quarters on two sides before going anywhere else, whilst it was almost impossible for patients to leave the building without passing by the medical staff through the illuminated central staircase and hall. ${ }^{39}$ Initially, the medical staff was small consisting of a matron, two nurses, a resident house apothecary and a secretary, whilst the three physicians and four surgeons attended periodically and according to a rota of duty days for emergencies. As was common in Georgian general hospitals, apart from emergencies, patients could be admitted only through the recommendation of subscribers or senior medical staff, with the number of recommendations being proportional to the amount subscribed. Again, as was usual, many types of patient were excluded, such as those who could afford their own treatment, pregnant women, children under the age of seven, prostitutes and those convicted of criminal offences ("without evidence of reformation of character"), the motive being to limit the

\footnotetext{
${ }^{39}$ Sylvester, op. cit., note 2 above, pp. $2-3$.
} 


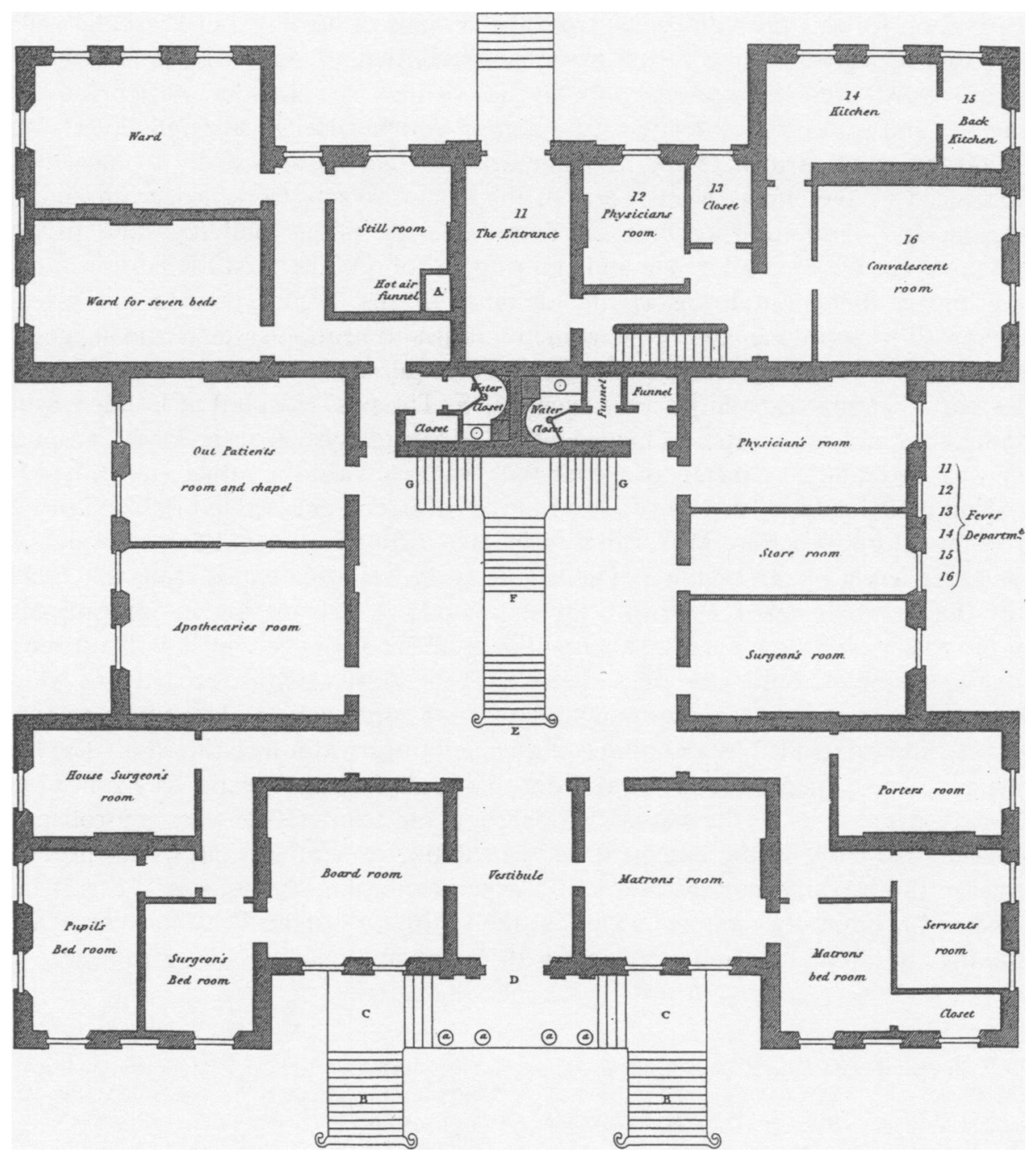

Figure 2: Plan of the middle storey of the Derbyshire Infirmary by W Lowry, from Charles Sylvester The philosophy of domestic economy, Nottingham, H Barnett, 1819. 


\section{Paul Elliott}

institution to those most amenable to cure amongst the "industrious" and "deserving" poor. ${ }^{40}$

The greatest technological innovations were in the interior of the Infirmary and also followed industrial models. In 1792 Strutt had devised a type of warm air stove and arrangement of flues and turncaps to warm and ventilate a mill at Belper. The inspiration for this probably came from the systems of heating and ventilation that had been designed by the textile manufacturers Richard Arkwright and Jedediah Strutt, which were themselves probably based upon the warming system of "fire engine" and wall cavities devised for Thomas Lombe's Derby silk mill (1721)-the prototype of all British textile manufactories. ${ }^{41}$ Strutt is also likely to have been influenced by the efforts of members of the Lunar Society to devise steam and air heating and ventilation systems for manufactories, public buildings and private houses. ${ }^{42}$ The Derby clockmaker and philosopher John Whitehurst FRS, for instance, a friend of Benjamin Franklin, the designer of the "Pennsylvanian fire place", attempted to apply the laws of Newtonian physics to heating systems and suggested that separate openings for ventilation were required besides chimneys. He also devised a heating and ventilation system for St Thomas' Hospital in London using under floor and wall ducts and hypercausts..$^{43}$ In Strutt's system at the Derby hospital, air was introduced by means of a four foot wide, 70 yard long duct and heated by an iron plated cubicle "cockle" or stove in the basement, encased in brick and placed over the fire under a grate. Warm air was directed through a series of ducts throughout the three levels of the building. The smoke from the fire escaped from the cockle into the flues by passing downward through two long, narrow slits on opposite sides of the cockle (see Figure 3, fig. 1). An outlet on the roof was provided with a turncap for the escape of foul air by flues connected with all the rooms for patients, whilst a second turncap away from the main building and connected to it by an underground culvert, was controlled by the power of a vane that turned it into the wind. The first turncap vane turned it always away from the wind. By these means, a current of air always passed through the wards. ${ }^{44}$ Circulation and temperature were controlled by situating the stove in the basement and calculating how much coal would produce different approximate temperatures. By experimentation, Sylvester and Strutt discovered the optimum economic value for the Infirmary system. They considered that making the air a "medium or vehicle for supplying caloric" at the Infirmary as

\footnotetext{
${ }^{40}$ Glover, op. cit., note 20 above, vol. 2, pp. 514-17.

${ }^{41}$ Gentleman's Magazine, 1732, 21: 940, 985-6.

${ }^{42} \mathrm{R}$ E Schofield, The Lunar Society of

Birmingham: a social history of provincial science and industry in eighteenth-century England,

Oxford, Clarendon Press, 1963, pp. 338-9.

${ }^{43} \mathrm{~J}$ Whitehurst, Observations on the ventilation of rooms; on the construction of chimneys; and on garden stoves, London, W Bent, 1794; Schofield, op. cit., note 42 above; M Craven, John Whitehurst of Derby, Ashbourne, Mayfield Books, 1996.
}

\footnotetext{
${ }^{44}$ Sylvester, op. cit., note 2 above, pp. 4-5; R Simpson, $A$ collection of fragments illustrative of the history and antiquities of Derby, Derby, G Wilkins, 1826, vol. 1, p. 451. The Hôpital St Louis in Paris (1607-12) had been constructed in a pavilion style, later to be favoured by Florence Nightingale. Here, the wards were ventilated through channels leading to the chimneys that were surmounted by a small cupola or open lantern above the roof. The air was drawn up through holes in the floors of the main wards to supplement the source from windows (Thompson and Goldin, op. cit., note 1 above, pp. 146-9).
} 


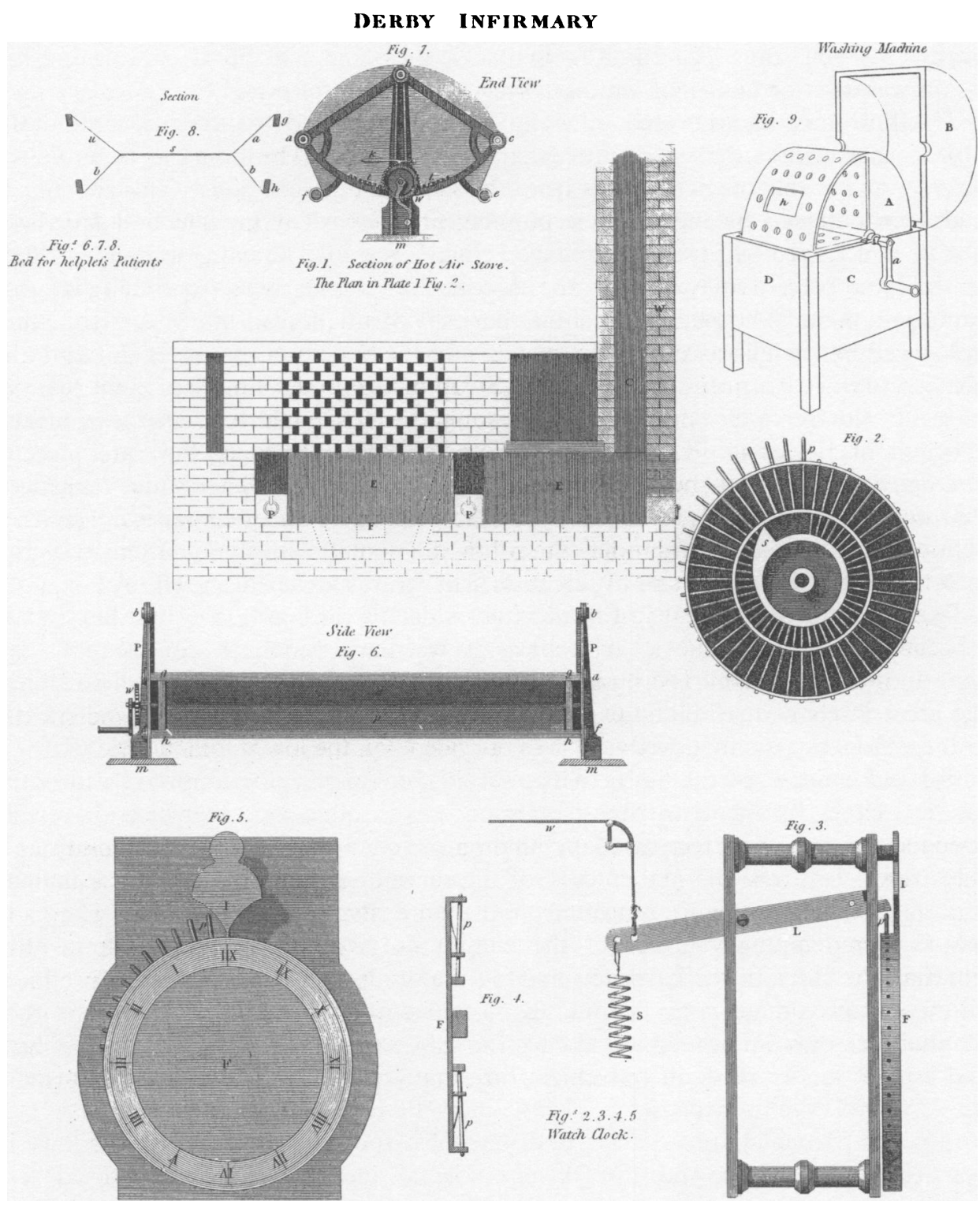

Figure 3: Engravings of the hot air stove, the washing machine, adjustable sick bed and watchman's clock utilized at the Derbyshire Infirmary, by W Lowry, from Charles Sylvester The philosophy of domestic economy, Nottingham, H Barnett, 1819. 


\section{Paul Elliott}

proven to be much safer, more effective and, especially, more economical than steam heating systems, thus, according to Sylvester, the same coal burnt in warming by steam was inferior to the air warming system at a ratio of 6 to $1 .^{45}$

The Infirmary incorporated other innovations designed to fulfil the utilitarian objectives of Strutt and the committee that had been inspired by industrial technology. There were baths in the basement warmed by steam and a wash house. This contained a revolving drum washing machine powered and heated by the steam-engine that had been designed by Strutt (see Figure 3, figs. 9 and 2). The baths were advertised in the local press and opened to the middle-class public, who were charged two shillings a time. ${ }^{46}$ A laundry dried the linen by the action of warm air from the heating system, whilst wet linen was passed into the hot closet on sliding horses with grooves to run across rails. In the kitchen Strutt incorporated a more efficient roaster of his own design and a new type of steaming apparatus, which he also used at his Derby home. Other innovations that became well known included the water closets and an adjustable sick bed, the former being based upon that of the Yorkshire inventor Joseph Bramah (1748-1814). Strutt's toilets flushed automatically by the action of the door as a person left the room and simultaneously admitted fresh air into the space, though it is not fully clear how the waste was disposed of.

By far the most frequent justification given for the design of the Infirmary, and especially the application of novel technology, was the economic advantage that they were thought to confer. The basis of the institution was "the principle of effecting the greatest good by the least expensive means". Thus it was constantly reiterated in the annual reports that treatment was provided "on the lowest practicable terms", whilst the expense of the warm baths would "in time ... be amply repaid with interest, either by the advantages, economy, or absolute income which they will produce: as may be exemplified by the ventilator, laundry, and warm bath respectively". Likewise the real efficacy of the thermo-ventilation system was that it was thought to require six times less coal than a steam heating system. The fact that-as contemporary critics of the committee noticed-the final cost of the Infirmary at $£ 17,870$ was 70 per cent above the original estimate of $£ 10,500$ despite all the rhetoric of "economy", doubtless provided another reason to emphasize the long-term economic, medical and public health benefits of the costly new technology and buildings. The subscriber could be sure that "tender care and kind treatment" were available "at an expense ... of little more than that of the food and medicine with which [patients] are supplied; and that these too [are] procured on the lowest practicable terms". The spectre of fever epidemics meant that wealthy subscribers would be, in effect, protecting themselves and their workforce by supporting the institution, as each fever case successfully treated in the infirmary "might have been ... a focus of infection, diffusing disease and perhaps destruction all around". Treatment prevented fever stalking "through the dwellings of the poorer classes of

${ }^{45}$ Sylvester, op. cit., note 2 above, pp. iv, 10 , $11,1213,16$ and 20; A F Dufton, 'Early application of engineering to the warming of buildings', Trans. Newcomen Soc., 1940-41, 21: 99-117; M C Egerton, 'William Strutt and the application of convection to the heating of buildings', Ann. Sci., 1968, 24: 73-87, 76-8.

${ }^{46}$ Sylvester, op. cit., note 2 above, pp. 6-8; Derby Mercury, 5 Aug. 1813; notices for the public baths, 1833, DRO, D1190/210/1. 


\section{The Derbyshire Royal Infirmary}

the community whose crowded apartments and wretched accommodations add strength to disease and give wings to infection ... whole districts are thus speedily exposed to the ravages of death-nor age, nor sex, nor condition has the means of security". 47

However, as we have seen, in the earliest specifications of the design committee from 1805, clinical considerations were also given some weight supported by the physicians Forester and Bilsborrow. Spatial control was achieved through the provision of small specialized wards to "enable the medical attendant to separate acute from chronic diseases and the former from each other as may kill the nature of their complaints"- an excellent illustration of the centrality of the Foucauldian power-knowledge axis. ${ }^{48}$ It was claimed that through the operation of the thermoventilation system "many lives" would be "preserved, which owing to a certain state of the air generally pervading Hospitals, might have been inevitably lost". ${ }^{49}$ Clinically inspired technological innovations continued to be made after the opening such as the adjustable bed mechanism, invented by Strutt after he had noticed that the nurses had great difficulty in turning over some patients without causing pain. Strutt's bed utilized a toothed wheel, ratchet and spring mechanism, allowing patients to be moved to any sideways position and held in place for comfort and easy treatment (see Figure 3, figs. 6, 7 and 8). ${ }^{50}$ In 1824 a new vapour bath was constructed "by which vapour and fumes of sulphur and other substances can be applied to the skin", whilst in 1825 a foot warmer was installed, heated by steam and covered by carpet, which could be used by eight people. The same year a small bath was constructed to a design by Sylvester for the use of the public, whose temperature could be precisely regulated by the user "according to their own pleasure". Also in 1825 , at a lecture to the Mechanics' Institute given by his brother the Infirmary surgeon Douglas Fox, the House surgeon and inventor Francis Fox demonstrated a steam vacuum cupping ball that had been developed utilizing the hospital's piped steam supply, and which it was claimed had been used "for many months ... in our excellent Infirmary ... with great success in the operation ... and consequently less [pain]". ${ }^{51}$ To these were added, in 1826, a "portable [fire] extinguishing engine" and, for the use of patients or the public, a "convenient, cheap, and simple steam or vapour bath", also designed by Francis Fox. To use the bath, the patient sat upon a common chair and was "surrounded up to the neck by an atmosphere of vapour at any desired temperature", this was said to have proved "very efficacious" in the treatment of "rheumatic affections"; whilst the other devices in general were considered to "have been found fully to answer the purposes for which they were designed", and could recoup money for the institution. ${ }^{52}$

\footnotetext{
${ }^{47}$ Third annual report, 29 Sept. 1812, DRO D1190/49/1.

${ }^{48}$ Report of the sub-committee, 4 Aug. 1804 , DRO D1190/1.

${ }^{49}$ Davies, op. cit., note 36 above, pp. 242-3.

${ }^{50}$ Sylvester, op. cit., note 2 above, pp. 48-9, plate v, 47-8, plate vii, figures 6 and 7 .
}

\footnotetext{
${ }^{51}$ Sylvester, op. cit., note 2 above, pp. 31-41; Douglas Fox, Notes on the lectures on anatomy and chemistry, Derby, W \& W Pike, 1826, pp. 45-6.

${ }^{52}$ Derbyshire Infirmary: fifteenth, sixteenth and seventeenth annual reports, 1824, 1825 and 1826.
} 


\section{Paul Elliott}

Table 1

Derbyshire General Infirmary: the state of inpatients at discharge, September 1809-September 1839

\begin{tabular}{lcc}
\hline State & Total Number & Percentage \\
\hline Cured & 7060 & 50.1 \\
Relieved & 1896 & 13.4 \\
At own request & 847 & 6.0 \\
For irregularity & 364 & 2.6 \\
Inpatients made outpatients & 2887 & 20.5 \\
Incurable & 438 & 3.1 \\
Dead & 609 & 4.3 \\
\hline Total & 14,101 & $(100)$ \\
\hline
\end{tabular}

Source: Annual reports

It is difficult to assess more exactly the clinical impact of the technology and design of the Infirmary, particularly the thermo-ventilation system, because of the quantity and indeterminacy of pertinent variables. As was common, the Derbyshire Infirmary produced statistics for the annual reports for the satisfaction of bourgeois subscribers, which stated the number of patients who were cured, relieved, excluded or who died, including outpatients treated by the dispensary that had also been opened in 1810. Some of these categories, such as that of patients discharged as "relieved", were highly subjective, whilst many factors need to be taken into consideration in assessing the significance of the mortality rates, such as the changing social, economic and demographic characteristics of the local population. However, analysis of the state of inpatients discharged between 1809 and 1839 gives an average mortality rate of 4.3 per cent (see Table 1) that compares quite favourably with other hospitals founded between 1740 and 1820 , which generally had rates of under 10 per cent. ${ }^{53} \mathrm{~A}$ comparison with quinquennial samples of the statistics of the state of inpatients discharged between 1839 and 1869 (Table 2) demonstrates that, although the proportion of those cured remained constant at around half of all patients discharged, the average mortality rate rose by 35 per cent. A comparison between the average mortality rates of the decades between 1809 and 1839 , and the quinquennial samples from 1839-1869 (Table 3), reveals that though the average mortality rate remained at around 3.5 per cent between 1809 and 1829, it rose significantly during the 1830 s to 5.4 per cent and remained at this level or higher for the ensuing decades.

The relatively low mortality rate suggests that the Derbyshire Infirmary was fairly successful by the standards of the period at treating disease, although how much

\footnotetext{
${ }^{53}$ At Shrewsbury and Liverpool for instance, the mortality rate rarely exceeded 7 per cent between the 1740s and 1820; Woodward, op. cit., note 1 above, pp. 153-8; A Borsay, 'An example
}

of political arithmetic: the evaluation of spa therapy at the Georgian Bath Infirmary, 1742-1830', Med. Hist., 2000, 45: 149-72. 
The Derbyshire Royal Infirmary

Table 2

Derbyshire General Infirmary: the state of inpatients at discharge, quinquennial samples, 1839-1869

\begin{tabular}{lcc}
\hline State & Total number & Percentage \\
\hline Cured & 2889 & 50.0 \\
Relieved & 600 & 10.4 \\
At own request & 365 & 6.3 \\
For irregularity & 115 & 2.0 \\
Inpatients made outpatients & 1387 & 24.0 \\
Incurable & 94 & 1.6 \\
Dead & 335 & 5.8 \\
\hline Total & 5785 & $(100)$ \\
\hline
\end{tabular}

Source: Annual reports

Table 3

Derbyshire General Infirmary: average mortality rates of discharged inpatients per decade

\begin{tabular}{cccc}
\hline $1809-1819$ & $1820-29$ & $1830-39$ & $\begin{array}{c}1839-69 \\
\text { (quinquennial samples) }\end{array}$ \\
\hline $3.6 \%$ & $3.5 \%$ & $5.4 \%$ & $5.8 \%$ \\
\hline
\end{tabular}

Source: Annual reports

this was due to the novel technology or other aspects of the design remains an open question. Early problems with the thermo-ventilation system may have contributed to the increase in mortality rate from the 1830 s. There were complaints from patients about the dryness giving "an unpleasant sensation"; however means were found, probably by Sylvester, of regulating the hygrometrical qualities of the air "without trouble or expense" ${ }^{54}$ In 1831 a pulley had to be fitted to one of the skylights in the operation room to improve the airflow, whilst smoke from the stew hearths escaped into the wards, and there were difficulties ensuring a free air flow into the ventilation tower. In 1842, the Master had to be instructed to encourage patients to use the convalescent rooms more frequently, and to see that windows were open as much and as often as possible. ${ }^{55}$ However, by far the most important factor is likely to have been the fact that by the $1830 \mathrm{~s}$, the population of the county town was expanding at a rate of 60 per cent, the most rapid in its history. ${ }^{56} \mathrm{~A}$ series of government health reports blamed the poor health of the town's inhabitants-shown

\footnotetext{
${ }^{54}$ Second annual report of the Derbyshire Infirmary, 29 Sept. 1811.

${ }^{55}$ Leveaux, op. cit., note 2 above, pp. 30, 33.

${ }^{56}$ Calculated from Davison, op. cit., note 18
}

percentage increase was 33.5 per cent, from 1821 to 1831 it was 35.6 per cent and between 1841 and 1851 it was just 8.5 per cent. 


\section{Paul Elliott}

most dramatically in outbreaks of typhus fever and childhood mortality rates - on the proliferation of poor quality court housing, the nature of factory employment, and pollution caused by smoke and poor drainage. It was noted that Derby's mortality rate at this time was 2.6 per cent, some 0.6 per cent above the national average, almost half of which was made up by child deaths under five years of age, and that the average life expectancy of labourers and artisans had fallen to twentyone years by 1840 as compared to forty-nine years for gentry or professionals. This resulted in a greater utilization of hospital capacity (though not at this stage overcrowding), which would have reduced the efficacy of hospital treatment and increased the chances of infection. ${ }^{57}$ This high mortality rate occurred despite the foundation of a Derby Self Supporting and Charitable Dispensary in 1830 and the medical assistance offered by the Poor Law Union from 1837. The former was served by a consulting physician and eight surgeons, with the local gentry enrolled as patrons, the facilities of the dispensary, being, like the Infirmary, open to members of the working classes not supported by the parish. ${ }^{58}$

\section{IV}

According to Edward Strutt, the Derby Infirmary had "in many respects, served as a model to similar institutions in England, and has obtained a well deserved celebrity even on the Continent". Writing in 1818, Sylvester referred to "the general admiration in which [the Infirmary] has been held, and the frequent applications that have been made from different parts of the kingdom, as well as from other countries, with a view to be acquainted with its merits". ${ }^{59}$ Although it is difficult to confirm this without a search of European and American hospital archives, there is evidence that the comments of Sylvester and Strutt were not hyperbole. The greatest influence that the Infirmary exerted was as a showpiece for the operation of Strutt's stove and thermo-ventilation system in public buildings, and indeed Sylvester placed the greatest emphasis on this in the Philosophy of domestic economy. Broadly, the influence of the Derby hospital is suggested in three different areas which will be briefly reviewed here, through published descriptions, through the visits of celebrities and writers and, of most importance, through incorporations of aspects of its building and technology in other public and private buildings-particularly medical institutions.

Descriptions of the Infirmary were published in various newspapers and topographical and descriptive volumes or town directories, including the Rev. Davies' New historical and descriptive view of Derbyshire, Glover's History of Derbyshire,

\footnotetext{
${ }^{57} \mathrm{~W}$ Baker, 'On the sanitary condition of the Town of Derby', in Local reports on the sanitary condition of the labouring population of England, London, W Clowes, 1842, pp. 162-82; J R Martin, 'Report on the state of ... Derby', in Second report of the Commissioners for Inquiring into the State of Large Towns and Populous Districts, London, W Clowes, 1845, vol. 2, pp. 270-80; E Cresy, Report to the Board of Health
}

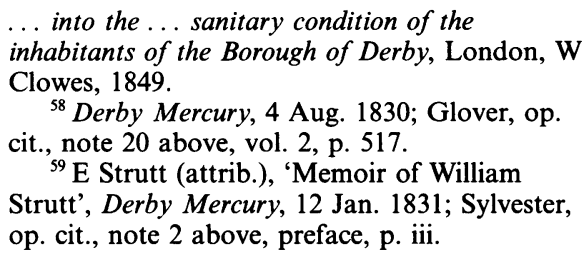




\section{The Derbyshire Royal Infirmary}

and Simpson's History and antiquities of Derby. Accounts also appeared in nationally published works such as Cooke's Description of Derbyshire, Lyson's Magna Britannia, the London encyclopaedia, and Phillips' Tour through the United Kingdom. ${ }^{60}$ All of these were highly favourable, as might be expected, although Phillips bemoaned the dependency of the institution on acts of charity such as the music festivals, which became quite well known in the region in their own right. ${ }^{61}$

A succession of visitors toured the Infirmary including natural philosophers, engineers, writers, medical men, royalty, politicians and architects. After William Edgeworth had visited the Strutts, his father Richard Lovell wrote to William Strutt referring to his house (in which technological innovations similar to those at the Infirmary had been applied to domestic economy), "where you seem to have exhausted all the resources of ingenuity in procuring domestic comfort for yourself and your friends". He gently condemned Strutt's "culpable indolence" in not publishing an account of the Infirmary "with the many admirable improvements that you have made in its economy". He thought highly of the washing machine but suggested that "perhaps a larger wheel (or drum) producing a greater fall in the linen and projecting pliable interrupters to turn the linen over in its fall might be advisable." 62 Sir Richard Phillips, on seeing St Helen's House in the 1820s, thought that "steam, gas, heat, hot air, philosophy and mechanics are all brought to bear on these premises, on every branch of domestic economy." ${ }^{33}$ Maria Edgeworth described how she had seen both the Strutt mills and the hospital:

Seven hours of the day Mr. Strutt, and his nephew Jedediah gave up to showing us the cotton mills: and another whole morning he gave up to showing us the Derby Infirmary; he built it - a noble building; hot air from below conveyed by a cockle all over the house. The whole institution a most noble and touching sight; such a great thing planned and carried into successful execution in so few years by one man.

On the same trip she met Forester, Elizabeth Darwin, Edward Strutt and Sylvester, whom she considered, "a man of surprising abilities, of a calm and fearless mind, an original and interesting character". ${ }^{64}$

The visits of royalty gave publicity to the Derbyshire Infirmary, receiving notice in the local and national press. In 1816 the Grand Duke Nicholas, later Nicholas I, Tsar of Russia (1796-1855), who was a friend of the Duke of Devonshire, before he

\footnotetext{
${ }^{60}$ Davies, op. cit., note 36 above, vol. 1, pp. 239-44; D and S Lysons, Magna Britannia, vol. 5, 'Derbyshire', London, T Cadell, 1817, p. 126; Simpson, op. cit., note 44 above, vol. 1, pp. 446-53; R Phillips, A personal tour through the United Kingdom, No. 2, 'Derbyshire and Nottinghamshire', London, Horatio Phillips, 1828, pp. 112-13; G A Cooke, Topographical and statistical description of the county of Derby, London, J Robins, 1830, pp. 71-3; Glover, op. cit., note 20 above, vol. 2, pp. 506-17; S Glover, History and directory of the borough of Derby, Derby, Mozley, 1843, pp. 34-6; The London
}

encyclopaedia; or, universal dictionary of arts, sciences and literature, 1839, vol. 2, pp. 173-4.

${ }^{61} \mathrm{~W}$ Gardiner, Music and friends, or, pleasant recollections of a dilettante, London, Longman, Orme, Brown, 1838, vol. 1, p. 490.

${ }^{62}$ Derby Mercury, 12 Jan. 1831; R L Edgeworth, letter to William Strutt, 1811, DLSL, Strutt Correspondence, D 125/-.

${ }^{63}$ Phillips, op. cit., note 60 above, pp. 111-17.

${ }^{64}$ Maria Edgeworth, letter to Honora

Edgeworth, 26 April 1813, in A J C Hare (ed.),

The life and letters of Maria Edgeworth, London, Edward Arnold, 1894, p. 52. 


\section{Paul Elliott}

visited anything else in Derby, was conducted "through the whole [Infirmary] building" with his entourage, the Duke, and Sir William Congreve (1772-1828), the natural philosopher, engineer and comptroller of the Woolwich Laboratory, which they "inspected with minute attention". ${ }^{65}$ The Grand Duke, reportedly, "highly admired the many ingenious and useful plans adopted in every department of the Institution" and was "much gratified by the evident attention which had been paid to the convenience and comfort of the patients". In 1819 he was followed by Prince Leopold of Saxe-Coburg, later King Leopold I of Belgium (1790-1865), who was conducted on a tour by Forester. ${ }^{66}$ With Leopold were, once again, the Duke of Devonshire, Sir William Gardiner, Prince Karl August von Hardenburg (1750-1822), the Prussian Chancellor, and Christian Friedrich, Baron Stockmar (1787-1863), the German diplomat and physician who was later to become a close friend of Queen Victoria and Prince Albert.

In both cases the royal parties and their entourages proceeded to tour the manufacturing and industrial premises of Derby and its surrounds after viewing the hospital, especially the Strutt cotton mills at Derby and Belper. Perhaps one of the most interesting results of Leopold's visit was the influence of Strutt's fireproof and iron-frame industrial architecture upon Hardenburg and Stockmar, and through these upon the Prussian architect Karl Friedrich Schinkel (1781-1841). Inspired by the accounts of his friend Stockmar, and no doubt their benefactor Hardenburg, with Peter Christian Beuth (1781-1853), Schinkel toured England in 1826 with the express intention of observing and sketching the latest examples of industrial and civil architecture, with particular emphasis on the new "fireproof" building techniques and the use of iron. ${ }^{67}$ After his own tours of the manufactories of England, Beuth excitedly told Schinkel in 1823 that the "wonders of recent times ... [were the] engines and buildings to contain them, named factories [where] the columns are of iron. The beams which rest on them as well. The perimeter walls are thin as paper and ... not even two-and-a-half feet thick". Clearly motivated by Stockmar and perhaps Hardenburg, Schinkel was, however, refused permission to observe the Belper mills by George Strutt, but he went on immediately to Joseph Strutt's house in Derby and was escorted around "the famous Infirmary" from which he produced detailed sketches. In his notebook Schinkel described it as:

[a] fine, pleasant building in every way. Magnificent staircase. The steps faced with lead plates. The famous hot-air heating, water-closet with shutters, movement of air in and out of the rooms, the stale air is drawn off by a rotating ventilator on the roof. Very practical cooking equipment. Magnificent baths, the anteroom through a canvas curtain, warmed by air wafted in from the bath ... everything thought out to the last detail. ${ }^{68}$

\footnotetext{
${ }^{65}$ Derby Mercury, 12 Dec. 1816. Accounts of the visit were also carried in other regional newspapers such as the Nottingham Review and Nottingham Journal.

${ }^{66}$ Derby Mercury, 14 Oct. 1819; Leicester Journal, 8 Oct. 1819; Nottingham Journal, 9 Oct. 1819; Nottingham Review, 15 Oct. 1819.
}

\author{
${ }^{67}$ B Bergdoll, Karl Friedrich Schinkel: an \\ architecture for Prussia, New York, Rizzoli \\ International, 1994, pp. 172-6. \\ ${ }^{68}$ Karl Friedrich Schinkel 'The English \\ Journey': Journal of a visit to France and Britain \\ in 1826, ed. D Bindman and G Riemann, New \\ Haven, Yale University Press, 1993, pp. 134-6.
}




\section{The Derbyshire Royal Infirmary}

He also specified the features of the washing and laundry system and described another Strutt-inspired stove and thermo-ventilation system at the Derby Lancasterian School. Schinkel was clearly excited by the application of industrial technology and the possibilities of iron-framed utilitarian, functionally inspired buildings and, as Hermann Lebherz has observed, drew on the inspiration of British industrial architecture to design one of his greatest buildings, the Berlin Bauakademie (Academy of Building), which in turn, influenced the Rationalist stream of German architecture down to the Modern Movement. ${ }^{69}$ In this respect, William Strutt's "fireproof" Derby and Belper manufactories and the Infirmary with its innovative industrial-inspired technology, bathing rooms, iron-framed windows and striking iron and glass dome, contributed to the important influence that British industrial buildings exerted on European architecture.

On 26 June 1817, two years before the publication of Sylvester's book, Strutt was made a fellow of the Royal Society, his five proposers being James Watt, Marc Isambard Brunel (1769-1849), James Lawson, Richard Sharp and Peter Mark Roget (1779-1869). In 1831, the President of the Royal Society, the Duke of Sussex, described Strutt as:

the author of those great improvements in the construction of stoves, and in the economical generation and distribution of heat, which have of late years been so extensively and so usefully introduced in the warming and ventilation of hospitals and public buildings. $\mathrm{He}$ possessed a very great knowledge of practical mechanics, and employed himself through the whole course of a very active life in the furtherance of objects of public ... utility. ${ }^{70}$

The efficacy of Strutt's Derby Infirmary design and technology in answering the requirements of patient control and treatment, whilst satisfying the demands of bourgeois economy, is evident from the inspiration that it gave to other hospitals. The structure and design of the Pauper Lunatic Asylum at Wakefield, Yorkshire, most closely followed that of the Derbyshire Infirmary; however, there is evidence that other hospitals including the Leicester Infirmary, the North Staffordshire Infirmary, the Nottingham Lunatic Asylum and the Bristol Infirmary, also reflected some influence, though the problems of incorporating Strutt/Sylvester thermoventilation systems in buildings already constructed was a limiting factor. In the United States, Charles Bulfinch (1763-1844), the architect of the Massachusetts General Hospital in Boston, read and annotated a copy of Sylvester's book whilst contemplating his own hospital designs. ${ }^{71}$ The governors of the Leicester Infirmary were one of the first medical bodies to express an interest when John Flint, the secretary of the Board, sent a letter to the Derby governors requesting information "on several points relative to the government of the hospital", though an offer by James Fox of Derby to install a steam-engine system similar to that

\footnotetext{
${ }^{69} \mathrm{H}$ Lebherz, 'Schinkel and industrial architecture', Architectural Rev., August 1988, 185: 41-6.

${ }^{70}$ Letter from Stephen Lee to William Strutt, 1 Dec. 1817, Strutt Correspondence, DLSL, D 125/-; Strutt obituary notice, Abstracts of the papers printed in the Philosophical Transactions of
}

the Royal Society of London, 1830-1837, 1860, 3: 84.

${ }^{71} \mathrm{~L} \mathrm{~K}$ Eaton, 'Charles Bulfinch and the Massachusetts General Hospital', Isis, 1950, 41: 8-11, reference from C Stevenson, 'Medicine and architecture', in Bynum and Porter (eds), op. cit., note 1 above, vol. 2, p. 1503. 
at the Derby hospital in 1812 was apparently not accepted. In 1814, Flint was asked by his Board to write to the infirmaries at Bedford, Derby, Nottingham and Northampton requesting information about the water closet systems because of sanitary problems at the Leicester Infirmary. Strutt's water closets were considered the best and the Leicester Board's architect, Thomas Cooke, visited the Derbyshire Infirmary to see if their system could be adapted. Reporting back favourably, he installed water closets on the Strutt model with ventilators, completing the work in July $1815 .^{72}$ Later, when a new fever house was being planned for the Leicester Infirmary, the architect William Parsons made a personal inspection of the Derbyshire Infirmary before designing a three-storey building with water closets on the second and third floors, and a thermo-ventilation system modelled on that at Derby, which was opened in $1820 .^{73}$ The design of the original North Staffordshire Infirmary at Etruria (1819) produced by the county surveyor Joseph Potter, also has some structural affinities with the Derby hospital with its symmetrical stone structure and central stair and light-well surrounded by wards. A Strutt/Sylvester thermo-ventilation system was installed with kitchen and laundry apparatus on the Derby plan. However, Sylvester complained that the system was not as effective as it should have been owing to mismanagement on the part of the builder. ${ }^{74}$

At Nottingham, Dr John Storer FRS (1747-1837), the chairman of the governors of the County Asylum, corresponded with Edward Long-Fox of Bristol on matters of iron fireproof structure, the need for galleries, and ventilation systems. Yet curiously, and despite the fact that Storer had been a member of the Derby Philosophical Society and would have known Strutt personally, the resulting Nottingham County Asylum (1810-12), designed by Richard Ingleman, did not originally contain a satisfactory heating or ventilation system. Edward Staveley, architect and surveyor, and $\mathrm{Mr}$ Dale, a member of the building committee, tried to install stoves, pipes, chimneys and other heating equipment, but Sylvester was subsequently called in to advise and had furnished a stove and thermo-ventilation system for $£ 100$ excluding materials by 1815 , which he suggested succeeded "very well". This was despite the fact that the original building was in his opinion, "of a most inconvenient form for warming" and "would have been more complete, if flues had been properly constructed in the first instance". 75 The governors of the Bristol Infirmary also took an interest in the structure and technology of the Derbyshire Infirmary, writing to the Derby governors in July

\footnotetext{
${ }^{72}$ Minutes and order books of the Derbyshire General Infirmary, 11 March 1811; E R Frizelle and $\mathrm{J}$ D Martin, The Leicester Royal Infirmary, 1771-1971, Leicester No. 1 Hospital Management Committee, 1971, p. 73.

${ }^{73} \mathrm{E} R$ Frizelle, The life and times of the Royal Infirmary at Leicester: the making of a teaching hospital, 1766-1980, Leicester, Leicester Medical Society, 1988, pp. 362-3.

${ }^{74}$ Sylvester, op. cit., note 2 above, preface, pp. viii-ix; R Hordley, A concise history of the rise
}

and progress of the North Staffordshire Infirmary and Eye Hospital, n.p., 1902, pp. 9-16.

${ }^{75}$ Sylvester, op. cit., note 2 above, preface, $p$. ix; I Inkster, 'Notes on the finance, building and technology in the early history of the lunatic asylum near Nottingham', Nottinghamshire County Records Office, Nottingham Archives, $\mathrm{SO} / 40 / 1 / 50 / 4 / 1$; I Inkster, 'Early history of the Nottingham Lunatic Asylum', Trent Vale Review, 1972, 9: 20-3. 


\section{The Derbyshire Royal Infirmary}

1816 requesting information specifically about the thermo-ventilation system. This was passed to Sylvester for an answer, which must have had some effect, for a governor of the Bristol Infirmary travelled to Derby in 1818 to consult Strutt about proposed improvements to the Bristol institution. ${ }^{76}$

Sylvester also acted as consultant to the Pauper Lunatic Asylum at Wakefield (1816-1818), which was designed by architects Watson and Pritchett of York, and in which a thermo-ventilation system, kitchen and washroom technology were installed exactly following the Derby pattern. Before passing through the stoves, as at Derby, fresh air gained admittance through flue entrances in two round towers on the top of which were turncaps to direct the inlets into the wind. It was then directed through flues in the bedrooms before escaping through another turncap in the roof similar to that in the dome of the Derby hospital. The separate male and female kitchens and laundry followed the Derby pattern, with a two horsepower steam-engine pumping the water, driving the washing machine and mangle, and providing steam from its enlarged boiler for the kitchen, baths and for water heating. The kitchen contained roasters, soup boilers and a steam-heated water tank, whilst the laundry included a drying closet with sliding horses as at Derby, though with the addition of a machine-driven washing machine and a new wringing machine which had been invented by Strutt after the Derby Infirmary kitchen had been constructed..$^{77}$

The publication of the Philosophy of domestic economy was partly designed to promote Sylvester's business activities, which were continued by his son John (1798-1852), who himself took out several patents between 1832 and 1845 . By 1817 as Strutt told Richard Edgeworth in a letter, Sylvester had almost completed a plant for the manufacture of improved air stoves utilizing the work that he and Strutt had done on domestic economy, which he continued on moving to London in $1820 .{ }^{78}$ Before this, Sylvester had supplied various private homes and non-medical public buildings including the New Jail at Maidstone and Leek Parish Church, and the homes of Strutt, Benjamin Gott, Samuel Shore, Sir Morton Disney and the sculptor, Francis Chantrey. Indeed, Sylvester stoves were installed on board ships such as the Erebus and the Terror, used by the Arctic explorer William Edward Parry. So technology originally developed for the Derbyshire Infirmary was later used in the search for a north-west passage. ${ }^{79}$ The Strutt/Sylvester stove and thermo-ventilation system were quite widely publicized with detailed descriptions appearing, for instance, in the works of Robert Meickleheim (under various pseudonyms) and in Rees' Cyclopaedia, where the success of the system at the Derbyshire Infirmary was

\footnotetext{
${ }^{76}$ Minutes and order books of the Derbyshire General Infirmary, 1 July 1816; W Strutt, letter to the Revd. W Burslem, 20 April 1818, Strutt correspondence, DLSL, D125/-.

${ }^{77}$ Sylvester, op. cit., note 2 above, appendix, pp. 57-62; C Watson and J P Pritchett, Plans, etc., and description of the Pauper Lunatic Asylum, York, 1819.

${ }^{78}$ Egerton, op. cit., note 45 above, p. 84; Sylvester, op. cit., note 2 above, p. vii. Taking
}

advice from Strutt, Richard Edgeworth employed iron-frame construction on buildings in Ireland, and his son William brought over the Strutt/ Sylvester stove.

${ }^{79}$ Sylvester, op. cit., note 2 above, p. viii-ix; Egerton, op. cit., note 45 above, p. 84; I M Leslie, Rosser and Russell Limited: the first two hundred years, London, West Central Printing Co., 1974; Inkster, 'Studies in the social history of science', op. cit., note 17 above, pp. 641-8. 


\section{Paul Elliott}

emphasized ${ }^{80}$ Strutt/Sylvester type thermo-ventilation systems were incorporated into the Hunterian Museum in London in 1810 (by Boulton and Watt), the Derby Lancasterian School, the Derbyshire County Hall and the Derbyshire County Prison, where John Sylvester's hot water heating and ventilation system could warm the cells to 34 degrees above that of the external air in a few minutes. ${ }^{81}$ The County Gaol in turn with the original Derbyshire Infirmary, Gloucester Asylum, Nottingham Asylum and Wakefield Asylum, all influenced the design of Henry Duesbury's Derby Lunatic Asylum at Mickleover (1844-51). This featured iron roofs with brick-arched "fireproof" ceilings, a thermo-ventilation system erected under the guidance of John Sylvester, baths, and kitchens and laundry containing washing machines, boiling vessels and a steam operated wringing machine, all driven or supplied with water or steam by a fifteen horsepower engine in the basement. The air was heated by hot water pipes and then circulated through the wards before being expelled through flues in the ceiling with the ventilation system operating through similar ducts and flues. ${ }^{82}$

\section{$\mathbf{V}$}

Constructed during the transitional period identified by Foucault during which the medical gaze became institutionalized and inscribed in social space, the design of the Derbyshire Infirmary is most significant as an early example of the application of industrially-inspired technology to general hospitals. As Enlightenment philanthropists and philosophers such as Howard and Bentham recognized, the problems of internal hospital spatial organization needed to service the sick members of an expanding and industrious workforce required efficient and economic clinical control. Hospitals isolated the sick from the healthy labouring population, as the rhetoric of hospital annual reports frequently emphasized. ${ }^{83}$ These requirements were satisfied in the Derbyshire Infirmary through the provision of a thermo-ventilation system, automatic flushing toilets and washing and drying apparatus, which allowed each wing of the institution to be self-sufficient. Small wards with separate lavatory provision and convalescent rooms positioned around an illuminated central staircase allowed control over patient movement and limited infection through isolation according to prevalent

\footnotetext{
80 'Stove', in Rees, op. cit., note 9 above, vol. 34; for Meickleham see W H Dickinson and A A Gomme, 'Robert Stuart Meickleham', Trans. Newcomen Soc., 1941, 22: 161-9.

${ }^{81}$ Glover, op. cit., note 60 above, pp. 49-51; Karl Friedrich Schinkel 'The English Journey', op. cit., note 68 above, p. 136. Similar systems were also installed at Kent County Asylum, Bath Gaol and the Model Prison at Pentonville.

${ }^{82}$ Thompson and Goldin, op. cit., note 1 above, pp. 74-6; H Duesbury (attrib.), Description of design for the proposed Derby
}

\author{
Pauper Lunatic Asylum, Derby, [1844]; Derby \\ proposed Lunatic Asylum: copies of the \\ objections of the Commissioners in Lunacy, \\ Derby, 1846, DRO; G H Gordon, History of the \\ Pastures Hospital, [Mickleover, Derbyshire, "The \\ Gateway", 1971]. \\ ${ }^{83}$ Though it is important to remember, as a \\ corrective to the Foucauldian emphasis upon \\ incarceration, that outdoor relief remained the \\ prominent form in England, at least until the \\ 1830 s, with the Derbyshire Infirmary generally \\ treating more outpatients than inpatients.
}




\section{The Derbyshire Royal Infirmary}

miasmic theory. ${ }^{84}$ Thus, through the application of industrial systems and experimental rationality, which allowed regulation of temperature, humidity and air flow, medical staff, acting for bourgeois subscribers, had almost complete control of the patient environment in the curing machine.

The efficacy of the late Enlightenment industrially-inspired designs for public institutions such as hospitals and prisons was evident in the popularity and influence of the Bentham brothers' Panopticon and in the influence of the Derbyshire Infirmary, shown by the incorporation of "fireproof" technology and similar thermo-ventilation systems in other institutions such as the Wakefield Lunatic Asylum. The spread of this industrially inspired and scientifically validated technology and organization to public institutions and eventually to domestic buildings was argued to have been an example of what Weber and the theorists of the Frankfurt School described as the onset of instrumental rationality, which was eventually to undermine the revolutionary radicalism and individualism of the Enlightenment as its values spread through the whole of society. This was especially apparent in medical institutions where Foucault's "medical gaze" and the psychological sciences opened up the body to experimentally validated clinical rationality, aided by technological development.

Finally, the case of the Derbyshire Infirmary and other institutions that feature industrially-inspired designs and technology also provides an interesting corrective to the arguments of econometric historians who have questioned the revolutionariness of the "Industrial Revolution" and the cotton industry's status as-in Rostow's phrase-the "leading sector", whilst emphasizing the slow rate of economic growth until the middle of the nineteenth century. ${ }^{85}$ The thermoventilation systems, fire-resistant structures and technology of the Derbyshire Infirmary and other similar institutions such as the Wakefield Lunatic Asylum, confirm that a broader qualitative conception of industrialization is required to support quantitative and statistically-based characterizations. This recognizes the breadth and complexity of the reciprocal influence of industrial behaviour, technology and instrumental rationality on culture and society, including public institutions and the domestic sphere. These institutions were the result of a

\footnotetext{
${ }^{84}$ The labourers who built the Infirmary were regulated by Strutt's watchman's clock (see Figure 3, figs 4 and 5), which already governed the workforce of his cotton mills and was to control the Derby watch, an excellent example of what E P Thompson has called "time sense in its technological conditioning", time-measurement "as a means of labour exploitation". E P Thompson, 'Time, work discipline and industrial capitalism', in idem, Customs in common, London, Penguin Books, 1993, pp. 352-403.

${ }^{85} \mathrm{~T}$ S Ashton, The industrial revolution, London, Oxford University Press, 1948; W W Rostow, The stages of economic growth,
}

Cambridge University Press, 1960; P Deane and W A Cole, British economic growth, 1688-1959, Cambridge University Press, 1967; C K Harley, 'British industrialisation before 1841: evidence of slower growth during the industrial revolution', $J$. Econ. Hist., 1982, 42: 267-89; S D Chapman, 'The cotton industry and the industrial revolution', in L A Clarkson (ed.), The industrial revolution: a compendium, Basingstoke, Macmillan Education, 1990, pp. 1-64; M Fores, 'The myth of the British industrial revolution', History, 1981, 66: 181-98; P K O'Brien and R Quinault (eds), The industrial revolution and British society, Cambridge University Press, 1993, pp. 1-30. 


\section{Paul Elliott}

conjuncture between industrial experience, experimental natural philosophy and medical knowledge and practice, evident in the involvement of members of the design committee in the Derbyshire iron industry, as they had been in the activities of the Lunar Society. 